\title{
GUIDANCE AND COUNSELLING FOR PUPILS WITH SPECIAL EDUCATIONAL NEEDS IN ACCRA, GHANA: IMPLICATIONS FOR INCLUSIVE EDUCATION
}

\author{
Sylvia Kabumle Ocansey ${ }^{a}$ and Prof. Emmanuel Kofi Gyimah ${ }^{b}$ \\ aPhD student, University of Pretoria, South Africa; ' University of Cape Coast, College of Distance \\ Education, Department of Education
}

\section{Vol 1 No 12019 \\ ISSN: 2788-6298 \\ DOI: https://doi.org/10.35293/tetfle.v1i1.67}

\begin{abstract}
Pupils with special educational needs require guidance and counselling services to overcome their social and psychological challenges. The study explored available guidance and counselling services in three special schools in Ghana. The concurrent triangulation mixedmethod design was used. The samples of pupils (88) and staff (3), comprising administrators and guidance and counselling coordinators were purposively selected for the study. Data were collected with a questionnaire and an interview guide. Quantitative data was analysed using descriptive statistics, specifically, frequencies and percentages while in the qualitative analysis, the thematic approach was used. The importance of guidance services was prevalent. The facility enabled discussions regarding pupils' educational goal construction, career plan development and solving relationship problems among pupils, their staff and parents. Regional Education officers were subsequently recommended to liaise with their counterparts at the Guidance and Counselling and Special Education Regional offices to monitor special schools, which will enable them to ensure widened service access and effective implementation.
\end{abstract}

Keywords: Guidance and Counselling, Inclusive Education, Special Schools, Special Educational Needs.

CONTACT Sylvia Kabumle Ocansey @ ocanseyarm@yahoo.com 


\section{Introduction}

The prevalence of socio-emotional and psychological concerns among pupils with special educational needs precipitate the need for diverse school support services. Guidance and counselling services seek to promote the academic objectives and overall development of pupils with special educational needs (Lununberg, 2012; Hamilton-Roberts, 2012). In Ghanaian educational institutions, guidance coordinators collaborate with other school staff for the implementation of effective guidance and counselling programmes. Guidance committees essentially comprise teachers (Ocansey, 2012) but the wide variety of school guidance activities necessitates other staff's assistance in the facility's execution. School guidance activities aim to establish a conducive learning environment that also nurtures pupils' growth. A key counselling objective in special schools is to facilitate disability identification and consultation for pupils (Clark \& Bremen, 2009).

Ghana has since early 2003 been piloting inclusive education in forty-five schools. The institutions are situated in the Greater Accra, Central and Eastern regions (Vanderpuye, 2013). In 2016, the policy draft for inclusive education, with highlights on the Universal Design for Learning (UDL) and the Child-Friendly School (CFS) models was launched in Accra. Both models stress education as a right for every child and further aims at promoting the fruitful development of pupils with special educational needs. Inclusive education implies mainstreaming pupils with special educational needs, instead of segregating them in special schools (De Boer, Pijl \& Minnaert, 2011). The educational reform sought primarily to contest discrimination against special needs pupils (Gyimah, Sugden \& Pearson, 2009) while promoting their attainment (Kalambouka, Farrell, Dyson, \& Kaplan, 2007), increasing access to, and participation in education (Walton et al., 2009). Aside ensuring enhanced educational resources for pupils' optimal education, the reform further introduced the term, 'pupils with special educational needs' to shift focus from the rather demeaning emphasis on handicaps and disabilities (De Boer et al., 2011). Special education refers to schooling for ethnic minorities or the socially disadvantaged (De Boer et al., 2011). Indeed, until the early 1990s, special schools were singularly responsible for the education of children with special educational needs. The institutions aimed at providing appropriate learning experiences for pupils (Simmons \& Bayliss, 2007). The 
introduction of inclusive education ensured the mainstreaming of special needs pupils to facilitate their overall advancement.

Special education concerns various disabled people and individuals with handicaps including the blind, learning disabled, mentally challenged, hearing impaired and children with Profound and Multiple Learning Difficulties (PMLD) (Simmons \& Bayliss, 2007). De Boer et al., (2011) also categorise pupils with communication, behavioural, motor skills, sensory and learning disorders, mental retardation, and pupils with chronic diseases as special needs pupils. Such children are also referred to as exceptional though the term exceptionality is more culturally inclined (Gargiulo, 2010). Indeed, Gargiulo (2010) simply describes such children as social deviants. The disabilities of such children may also be single or multiple (Altun, Guven, Akgun, Akkurt, Basak \& Akbulut, 2010), often handicapping them by inhibiting the children's capacity to perform specified tasks normally. Disabilities are also usually biologically initiated, emerging from body muscle or organ loss, malfunctioning, or paralysis (Gargiulo, 2010) that generally interferes with the child's ability to accomplish his expected educational, social and vocational potential (Pijl, Frostad \& Flem, 2008). The deformity may also be physical, developmental, cognitive, or affective in nature (Altun et al., 2010). In developed countries, people with disabilities represent as much as ten percent of the population, but the percentage slightly appreciates in developing countries (Altun et al., 2010). In Ghana, the Special Education Division of the Ghana Education Service manages the entire service (Kyere, 2009).

Teachers remain key partners in the successful educational reform implementation (De Boer et al., 2011). Their strategic position in establishing daily direct contact with pupils emphasizes their role in the implementation process. According to Giangreco, Suter and Doyle (2010), efficient collaboration with teacher aides in inclusive classrooms is a basic necessity. The assistive roles of such aides regarding teachers' efforts (Rose \& O'Neil, 2009) has resulted in their sudden upsurge in English and Irish inclusive schools in recent times (Department for Education and Skills, 2007; Ochai, 2011 as cited by Oluka \& Eke, 2015). Nonis and Jernice's (2011) for that matter underscore the positive attitudes of pre-service teachers in Singapore towards inclusion, likewise, Sweetland (2008) who describes teachers as generally caring, supportive and determined to construct worthwhile interpersonal relationships to 
optimise pupils' learning opportunities in inclusive institutions. However, Rose, MondaAmaya and Espelage (2011) also identified bullying and the victimisation of disabled pupils as further severe difficulties confronting pupils in American institutions. Lack of classroom assistants (Black-Hawkins et al., 2007) to meet the 'demanding' needs of special needs pupils (Ainscow, 2007) was also not left out of the numerous challenges pupils often encounter.

Literature, however, underscores poor inclusive and woefully inadequate school resources, particularly in Ghana (Agbenyagah, 2006 \& 2007; Ocloo \& Subbey, 2008). Inappropriate school practices, lack of proper resources amidst poor teacher special skills, gravely threaten the smooth reform implementation process. Teachers have also been identified as key perpetrators of challenges for pupils with special educational needs in Ghana. Their uncompromising use of corporal punishment for example, though strongly prohibited in inclusive schools, confirms their poor attitude towards the educational reform (Agbenyagah, 2006 \& 2007). Kuyini and Mangope (2011), as well as Ocloo and Subbey (2008), also endorse the report of poor teacher and stakeholders' attitude towards inclusion. Oluka and Eke (2015) however, attribute the trend to the staffs' dislike for pupils with learning disabilities in their classrooms. On their part, teachers cited systemic inadequacies including poor skills training and lack of appropriate facilities to justify their low attitudes towards the reform.

Gyimah et al., (2009) likewise refuted Agbenyega's (2006) earlier submissions regarding low teacher attitudes. The authors explained that teachers in Ghana cared about pupils in various categories of special educational needs. Yet, all is not rosy for the pupils in special and inclusive schools. Reports of prevalent depression and rejection in related Ghanaian institutions equally highlight the immense psychological and emotional challenges encountered by pupils (Agbenyega, 2007; Oluka \& Eke, 2015). The duties of classroom assistants are critical in boosting pupils' selfconfidence, sharpening their attention on assigned tasks and promoting their overall participation in class (Ainscow, 2007). The mentioned difficulties indeed derail the very purpose of inclusion for pupils with special educational needs.

School guidance services comprise a combination of seven services with counselling as the core. School counselling aims to facilitate pupils' emotional, social and mental 
support to actualise their educational objectives. Guidance and counselling facilities usually assist pupils encountering confusion, fear, discrimination, and bullying, both at home and in school (Hamilton \& Roberts, 2012). In Ghana, Guidance coordinators function to promote pupils' self-understanding, self-direction, and meaningful adjustment for an overall productive life (Oluka \& Egbo, 2014). In special schools, Guidance counsellors are responsible for redressing the attention difficulties, fixation to routines and mood challenges of pupils with special educational needs (Oluka \& Eke, 2015). The counsellors additionally facilitate pupils' self-understanding, their construction of positive self-images and also motivate them towards increased studies for better school achievement (Obani, 2006). Parents of pupils with special educational needs likewise require counselling to construct positive skills in caring for their children with special educational needs (Charema \& Eloff, 2011). Bitsika \& Sharpley, (2004) for instance, reported that many parents encounter stress and depression as a result of the challenges they face in understanding and relating meaningfully with their children with special needs. In line with this idea, the Welsh Assembly stressed on the importance of counselling by demanding an effective service for pupils in all Local Authority schools (National Strategy Paper, WAG, 2008). Efficient guidance and counselling services are thus desirable to facilitate schooling among pupils with special educational needs.

The inclusive education policy goal to establish worthwhile schools aligns with the current study focus that re-echoes facilitating needed efforts to augment overall school environments. This reflects a comprehensive educational agenda which agrees with Ghana's 1992 constitution portion that highlights; equal rights to education for all (Amenya, 2009; Republic of Ghana 1992) as well as the Free Compulsory and Universal Basic Education (FCUBE) policy (Agbenyagah, 2006). The current study accordingly sought to examine existing guidance and counselling services in special schools in Ghana. An investigation of the service to address inadequacies both in inclusive and special schools is a worthwhile effort (Rose \& O'Neill, 2009).

Inclusive education and special schools stress worthwhile and supportive school environments. The aims of both institutions (inclusive schools and special schools) are currently challenged by various shortcomings (Agbenyega, 2007; Oluka \& Eke, 2015). Reports of bullying, victimisation and depression have become the order of the day 
within the confines of such institutions in recent times. However, lack of appropriate interventions to redress the social and emotional challenges of pupils with special educational needs continue to hamper their fruitful education. Little or no records additionally exist on available guidance and counselling services in the mentioned educational settings although the guidance facility has been proven to be extremely worthwhile (Clark \& Breman, 2009). The reports confirm the inadequacy of support for pupils in special and inclusive schools (Mprah et al., 2015). Oluka \& Egbo, (2014) specifically observe that pupils acquire positive and independent learner attitudes while constructing holistic personalities with consistent guidance and counselling services. In accordance with efforts to ensure efficient education for pupils with special educational needs in Ghana, the goals of the current study cannot be overemphasised.

\section{Theoretical Framework}

Carl Rogers' Client-centred theory underpins the current study. A key concept of the theory is that every human being has a natural tendency to seek growth, constructive change, and life enrichment (Allen, 2015). This calls for the counsellor to believe in the client's inherent self-actualising tendencies to realise his personal advancement. Indeed, the title 'every person is to be prized' (Allen, 2015, p12) simply speaks volumes in this circumstance. Another core concept is that every human being has a value or worth that demands respect from others, particularly the counsellor (Babilonia, 2016). Rogers accordingly proposes a warm, respected, and supportive counsellor-client relationship to promote the achievement of counselling goals. Indeed, the counsellor's warmth and acceptance motivates the client into realising his/her potential. It is critical in this theory that counsellors also remain genuine and non-directive in promoting the achievement of counselling goals (Babilonia, 2016). In line with the theory, pupils with special educational needs undeniably have value and worth and desire respect and warmth from significant others (Counsellors, teachers and parents). The support and warmth from significant others, in fact, serves a motivating purpose to promote the pupils' development into a fruitful future. The current study focus thus aligns perfectly with the client-centred theory, given the positive goal of school guidance and counselling services. Instead of mocking, bullying and teasing them, peers, parents and teachers should instead endeavour to support these pupils to enable them actualise their potentials. 


\section{Research question}

The following research questions guided the study:

1. What are the guidance and counselling activities available for pupils with special educational needs in special schools within the Greater Accra region of Ghana?

2. What roles do school staff play in offering guidance and counselling services to pupils with special educational needs in special schools within the Greater Accra region of Ghana?

\section{Research Methods}

The concurrent triangulation mixed method design was employed for this study. This design is one directed towards determining the nature of a phenomenon as it exists at the time of the study (Maduabum, 2004). The study population consisted of three Special Schools in the Greater Accra region of Ghana, two of them were public and the remaining one private. The total population in the studied schools was 508 , comprising 254 in school A, 115 in school B and 139 in school C. Details of the population distribution among the three schools are shown in Figure 1.

Figure 1: Population distribution of the respondents

\begin{tabular}{cccccccc}
\hline School Name & $\begin{array}{c}\text { Down's } \\
\text { syndrome }\end{array}$ & $\begin{array}{c}\text { Cerebral } \\
\text { Palsy }\end{array}$ & Autism & $\begin{array}{c}\text { Emotionally } \\
\text { Disturbed }\end{array}$ & $\begin{array}{c}\text { Mild Brain } \\
\text { Damaged }\end{array}$ & $\begin{array}{c}\text { Hearing } \\
\text { Impaired }\end{array}$ & Grand Total \\
A & - & - & - & - & - & 254 & 254 \\
B & 31 & 23 & 23 & 38 & - & - & 115 \\
C & 95 & 25 & 5 & - & 14 & - & 139 \\
Total & 126 & 48 & 28 & 38 & 14 & 254 & 508 \\
\hline
\end{tabular}

\section{Sampling technique}

Purposive sampling technique was used to select the three special schools (A, B and C). This sampling procedure was used because, the schools fit into the sampling criteria of being "special schools". Again, in the selection of the pupils who will serve as the respondent of the study, purposive sampling technique was used for each of the three schools. This sampling approach was deemed right because the nature of the pupils' condition is such that some are unable to express themselves meaningfully in oral or written language. In view of this, the researchers purposively selected pupils who could express themselves well, either orally or in written language. In specific 
terms, 57 pupils were taken from school 'A', 22 pupils from school 'B' and 11 pupils from school ' $C$ '. The samples from the three schools were put together to make one case, thus totaling a sample size of 88 participants. Aside pupil selection, a school administrator from two schools and one Guidance and counselling coordinator from the third institution were also purposively selected to be engaged in the study. Details of the sample distribution are shown in Figure 2.

Figure 2: Sample distribution by gender

\begin{tabular}{cccccccc}
\hline $\begin{array}{c}\text { Name of } \\
\text { school }\end{array}$ & Male & Female & Total & Male & Female & $\begin{array}{c}\text { Sample } \\
\text { Admin. / } \\
\text { Guid. }\end{array}$ & Totals \\
School A & 135 & 119 & 254 & 16 & 40 & 1 & $\mathbf{5 7}$ \\
School B & 71 & 44 & 115 & 18 & 4 & 1 & $\mathbf{2 3}$ \\
School C & 86 & 53 & 139 & 7 & 3 & 1 & $\mathbf{1 1}$ \\
Totals & $\mathbf{2 9 2}$ & $\mathbf{2 1 6}$ & $\mathbf{5 0 8}$ & $\mathbf{4 1}$ & $\mathbf{4 7}$ & $\mathbf{3}$ & $\mathbf{9 1}$ \\
\hline
\end{tabular}

\section{Instrument(s)}

Self-designed questionnaire and a semi-structured interview guide were used as instruments of the study. Items on both instruments were derived from literature and they were all based on the research questions. The questionnaire was a four-point Likert type of scale ranging from strongly agree, agree, disagree and strongly disagree. The instruments were pilot-tested in two special schools in Central region, Cape Coast. In the pilot-testing, 20 children with special needs were engaged for the questionnaires and one administrator and one guidance and counselling coordinator were also interviewed. The pilot testing was done purposely to fine-tune the instrument in order to improve its validity and reliability (Cohen, Manion \& Morrison, 2007). The Cronbach Alpha reliability coefficient of 0.67 was attained for the questionnaire, after its refinement.

\section{Ethical Consideration}

In accordance with qualitative research ethics, permission was sought from all relevant gate-keepers, before data collection commenced in the selected schools. Initial telephone calls were made to all three school heads for briefing and to seek permission. Letters were subsequently sent to the school heads for documented 
approval while parents' letters for approval were accordingly distributed. Researchers ensured that replies from parents of the selected pupils were received in good time. All the gatekeepers including parents were equally assured of confidentiality and anonymity of the engaged pupils' identity. Teachers and resource persons also discussed the study with pupils and assured them of confidentiality. The pupils then volunteered their participation in the study but the few who objected to their engagement were left out.

\section{Data Collection Procedure}

Data collection spanned a total of four weeks. Familiarisation visits were made to the Schools during which letters of introduction and requests for permission were presented to the school heads and parents. Convenient dates were then agreed on for the commencement of data collection. The researchers collected the data themselves with interpretation assistance from teachers in each school. In schools $B$ and $\mathrm{C}$ for instance, data collection dragged on more, due to the interference of the pupils' disabilities. Teachers also sometimes had difficulties explaining some questionnaire items to the pupils while some pupils also encountered difficulties responding coherently to the questionnaire items. Some pupils were also found to provide responses that were unrelated to the questions asked. A few other participants also did not respond to some items. In school A, however, the one-on-one method of questionnaire administration was easily applicable following the researchers' reliance on teachers to utilise the sign language and lip reading to explain questionnaire items to the pupils. Furthermore, on the part of adult respondents, one-on-one face to face interview sections were held for the selected school administrators and guidance and counselling coordinator at their convenience in their respective schools. Permission was also sought from the respondents to audiotape their sessions after meaningful rapport was established with each of them.

\section{Data Processing and Analysis}

The four scales of item responses were converged into two - agree and disagree for easy analysis. Frequencies and percentages were used to analyse the data whereas thematic analysis was used for the qualitative data. 


\section{Results}

Table 1: Results on guidance and counselling-related activities in the studied schools

\begin{tabular}{|c|c|c|c|c|c|}
\hline \multirow[t]{2}{*}{ Item Content } & \multirow{2}{*}{$\begin{array}{l}\text { Name of } \\
\text { School }\end{array}$} & \multicolumn{2}{|c|}{ Agree } & \multicolumn{2}{|c|}{ Disagree } \\
\hline & & No. & $\%$ & No. & $\%$ \\
\hline \multirow{3}{*}{$\begin{array}{l}\text { I think school guidance and counselling services } \\
\text { are important for pupils with special educational } \\
\text { needs. }\end{array}$} & School A & 45 & 80.3 & 11 & 19.7 \\
\hline & School B & 22 & 100 & 0 & 0.0 \\
\hline & School C & 10 & 100 & 0 & 0.0 \\
\hline \multirow{3}{*}{$\begin{array}{l}\text { I easily get someone at school to discuss my } \\
\text { future education, whenever I need it. }\end{array}$} & School A & 46 & 82.1 & 10 & 17.9 \\
\hline & School B & 20 & 90.9 & 2 & 9.1 \\
\hline & School C & 10 & 100 & 0 & 0.0 \\
\hline \multicolumn{6}{|l|}{ Table 1, Continued } \\
\hline \multirow{3}{*}{$\begin{array}{l}\text { I easily get someone at school to discuss my } \\
\text { future career plans, whenever I need it. }\end{array}$} & School A & 47 & 83.9 & 9 & 16.0 \\
\hline & School B & 19 & 86.4 & 3 & 13.6 \\
\hline & School C & 9 & 90.0 & 1 & 10.0 \\
\hline \multirow{3}{*}{$\begin{array}{l}\text { I get good counselling services at school } \\
\text { whenever I want to discuss my academic } \\
\text { performance with someone. }\end{array}$} & School A & 45 & 80.3 & 11 & 19.7 \\
\hline & School B & 19 & 86.3 & 3 & 13.6 \\
\hline & School C & 9 & 90.0 & 1 & 10.0 \\
\hline \multirow{3}{*}{$\begin{array}{l}\text { I often join my colleagues at school for school } \\
\text { guidance and counselling activities. }\end{array}$} & School A & 46 & 82.2 & 10 & 17.9 \\
\hline & School B & 18 & 81.8 & 4 & 18.2 \\
\hline & School C & 10 & 100 & 0 & 0.0 \\
\hline \multirow{3}{*}{$\begin{array}{l}\text { My school staff are willing to listen to and protect } \\
\text { me whenever my friends maltreat me. }\end{array}$} & School A & 42 & 75.0 & 14 & 25.0 \\
\hline & School B & 20 & 90.0 & 2 & 9.1 \\
\hline & School C & 10 & 100 & 0 & 0.0 \\
\hline \multirow{3}{*}{$\begin{array}{l}\text { Whenever my parents or siblings abuse me at } \\
\text { home, I easily get a school staff to comfort me and } \\
\text { talk it over with my family members. }\end{array}$} & School A & 40 & 71.5 & 16 & 28.6 \\
\hline & School B & 21 & 95.4 & 1 & 4.5 \\
\hline & School C & 8 & 80.0 & 2 & 20.0 \\
\hline \multirow{3}{*}{$\begin{array}{l}\text { I mostly join my school team whenever they are } \\
\text { going on an excursion or a school outing } \\
\text { programme. }\end{array}$} & School A & 48 & 85.8 & 8 & 14.3 \\
\hline & School B & 21 & 95.4 & 1 & 4.5 \\
\hline & School C & 9 & 90.0 & 1 & 10.0 \\
\hline \multirow{2}{*}{$\begin{array}{l}\text { I learnt about my interest areas and hobbies } \\
\text { through a school programme. }\end{array}$} & School A & 42 & 92.8 & 4 & 7.2 \\
\hline & School B & 19 & 86.4 & 3 & 13.6 \\
\hline
\end{tabular}




\begin{tabular}{l|c|c|c|c|c}
\hline \multicolumn{1}{c|}{ Item Content } & Name of & \multicolumn{2}{c|}{ Agree } & \multicolumn{2}{c}{ Disagree } \\
\cline { 4 - 7 } & School & No. & $\%$ & No. & $\%$ \\
\cline { 2 - 7 } & School C & 9 & 90.0 & 1 & 10.0 \\
\hline I easily access counselling services in my school & School A & 26 & 46.4 & 30 & 53.5 \\
\cline { 2 - 7 } \\
whenever I need it. & School B & 19 & 86.4 & 3 & 13.6 \\
\cline { 2 - 6 } & School C & 9 & 90.0 & 1 & 10.0 \\
\hline
\end{tabular}

Study findings regarding available school guidance services were encouraging. Pupils essentially recorded their satisfaction with the staff's immense roles in providing them with relevant support services. This resulted in the numerous benefits and enjoyment they derived from the provided support services. All pupils from Schools B and $C$ and majority ( $n=45,80.3 \%)$ of the pupils from School A acknowledged the significance of school guidance and counselling services to their education. Similarly, majority of pupils, $(n=42,92.8 \%),(n=9,90 \%)$ and $(n=19,86.4 \%)$ from all three schools, $A, B$ and $C$ respectively further acknowledged learning about their interest areas and hobbies from the support services they enjoyed in their institutions. An equally high majority $(n=46,82.2 \%)$ from school $A,(n=18,81.8 \%)$ from School B and all pupils, $(n=10$, $100 \%$ ) from school $C$ reported joining their colleagues at school for guidance-related excursions.

Furthermore, majority $(n=46,82.1 \%)$ and $(n=20,90.9 \%)$ from Schools $A$ and $B$ respectively and all, $(n=10,100 \%)$ from School $C$ additionally confirmed easily accessing a school staff to discuss their future education issues with them. Other support services received from school staff includes holding discussions with pupils regarding their future career plans, $(n=47,83.9 \%)$ from School $A,(n=19,86.4 \%)$ from School $B$, and $(n=9,90 \%)$ from School C. Majority $(n=45,83.3 \%)$ from School $A$, $(n=19,86.3 \%)$ from School $B$, and $(n=9,90 \%)$ from School C also acknowledged easily accessing a staff member to discuss their academic performance with them. The school staff were further found to avail themselves to discussing pupils' complaints but also protected them from maltreatment by their friends. Forty-two (42) pupils representing (75\%) from School $A,(n=20,90.9 \%)$ from School B and finally, all ( $n=10,100 \%)$ from School $C$ made the report regarding staffs' protection and pupils' complaints. Whenever pupils with special educational needs were abused by siblings and parents at home, a high percentage of pupils $(n=40,71.5 \%),(n=8,80 \%)(n=21$, 
91.4\%) from all three schools reported finding a staff member to comfort them and talk things over with their families.

However, apart from the majority of pupils in school $B(n=19,86.4 \%)$ and $(n=9,90 \%)$ in school $\mathrm{C}$ who reported easily accessing school counselling services whenever they needed it, only a few $(n=26,46.4 \%)$ from School A confirmed enjoying such a facility at school. Indeed, majority $(n=30,53.5 \%)$ of pupils in school $A$, confessed not being able to access counselling whenever they most needed it. It is essential to consider the concerns of such a significant percentage of pupils in School $A$ being denied counselling, despite the service's importance among pupils with special educational needs (The Estonian Ministry of Education \& Research, 2014; Oluka \& Egbo, 2014).

\section{Discussion}

School guidance and counselling services were essential to many participants in the study. Participants reportedly used the facility to meet their relationship, career, educational and academic needs. Results revealed the majority of pupils in all three schools acknowledging the significance of guidance and counselling services in promoting their education. Pupils relied heavily on the service to discuss their academic performance (refer to Table 1 item 4), plan their future education (table 3 item 2), and career paths (Table 1 item 3). Others were also content when school staff intervened in the conflicts they encountered with parents (Table 3 item 7) and their peers (Table 3 item 6). These findings agree with Logan (2006) and Oluka and Eke, (2015) who opined that support services positively enhanced schooling for pupils with special educational needs. The socio-emotional and psychological support pupils also received from the counselling service were also well-appreciated. According to Clark and Breman (2009), the counsellor's role in identifying, placing and consulting with parents regarding the Individualised Education Programme (IEP) for special needs pupils remains core to inclusive education. IEP facilitates the application of appropriate school resources to meet the direct educational needs of identified pupils. Guidance and counselling services in this regard also aligned with Rogers' client-centred counselling theory to promote the pupils' potential for personal development.

Furthermore, the intervention of school staff in the academic and career concerns of the pupils additionally meets their emotional needs. Such support often boosts the 
pupils' self-confidence and urges them on into achieving their personal potential. This study result particularly confirms the importance of extra classroom support as a crucial factor in the progress of inclusive schools (Rose \& O'Neil, 2012). The assistants' encouraging roles regarding pupils' overall participation and improved academic performance in inclusive schools (Black-Hawkins et al., 2007) is a worthwhile guidance-related facility. Incidentally, the researchers witnessed some student attendants on an internship from the University of Ghana in School B during data collection. The role of such teacher aides in propelling the pupils' studies cannot be over-emphasised.

Staffs' interview reports in all three schools further stressed the immense role of guidance and counselling in promoting the holistic development of pupils with special educational needs. The staffs' submissions regarding talk programmes on grooming for female pupils in School A, for instance, is critical to their fruitful future development. The Guidance coordinator firmly stressed the female pupils' maintenance of personal hygiene during their menstrual periods. She also mentioned encouraging the girls to maintain low haircuts and well-combed hair, clean fingernails, and neat clothes at all times to remain healthy. To quote from her direct report, the guidance coordinator, for instance, noted during her interview that: -

'We take time to groom these girls so that they can keep themselves neat and dress well during their menstrual periods. As part of our educational responsibilities, we must ensure that they grow into responsible adults, who value the norms of the Ghanaian society.' (interview script)

Such orientations often reduced the incidence of irresponsible and problematic behaviours among young people (Njoka, 2007). Additionally, in School B, the

Administrator noted that: -

'excursions to social places of interest, are termly organized by the school to enable pupils [to] learn more about their society. Such activities further provided relevant recreation as well as career information to pupils.' (interview script) 
The administrator further emphasised that: -

'the school ensured that teachers often accompanied pupils on such outings to enhance learning experiences and ensure the safety of pupils'. (interview script)

In School C, the Administrator identified sporting activities as vital to the physical and psychomotor development of the pupils. It was on one such sports day that the researchers arrived at the school for data collection. This explains the availability of only a few less expressive and agile-minded pupils for the questionnaire administration. The emphasis on sports, in this case, aligns with the expression, ' $a$ healthy mind lives in a healthy body'. Pupils' sporting interest in School C was critical to their healthy development. Sports also has a guidance-related focus given that it promotes the physical development of pupils.

Overall, the staffs' interest in promoting the lives of pupils in the three selected special schools aligns with the client-centred theory's optimistic focus. Roger's emphasis on counsellors to show acceptance and warmth towards clients reflects the supportive element of guidance and counselling staff within the school setting. The staffs' show of care also endorsed Rogers' counsellor congruence as a core condition of the clientcentred theory.

Contrarily, the finding regarding pupils' inability to easily access direct counselling support in School A (refer to Table 3, item 10) was problematic. Given the documented importance of counselling in the literature (Hamilton-Roberts, 2012; Estonian Ministry of Education \& Research 2014), the result defeats the very basis or rationale behind establishing school counselling. This requires immediate redress to facilitate pupils' emotional and psycho-social development in the school.

Finally, the results show that pupils in all three studied schools were fairly involved in school support services, and also acknowledged benefiting immensely from the facility. This result equally endorses the importance of the client-centred theory. The staffs' extended love and acceptance to parents of pupils with special educational needs aligned with genuine counsellor interest and care in ensuring the pupils' fruitful advancement. Such useful parent-teacher collaborations also depict worthwhile 
counselling orientations to improve parental interactions with their special needs children. Reports of parental stress and depression due to ignorance in relating with their wards with special educational needs at home will soon be extinct (Bitsika \& Sharpley, 2004; Charema \& Eloff, 2011) as staff consistently counselled parents regarding their relationships with their special needs children. Such support assures the pupils of reliable and comforting relations with significant others.

The researchers also noted the vocational emphasis in all three schools. Vocational activities such as bead-making, weaving, sewing and batik-tie and dye were found to have significant teaching focus in all the three selected special schools. This reflects the key role skills training, and future employment plays among pupils with special educational needs. Warnock and Norwich (2010) recommend a vocationally-focused curriculum for pupils with special educational needs. The authors stressed the future benefits of such a curriculum for all pupils.

Figure 1: - The proposed guidance and counselling model for pupils with special educational needs

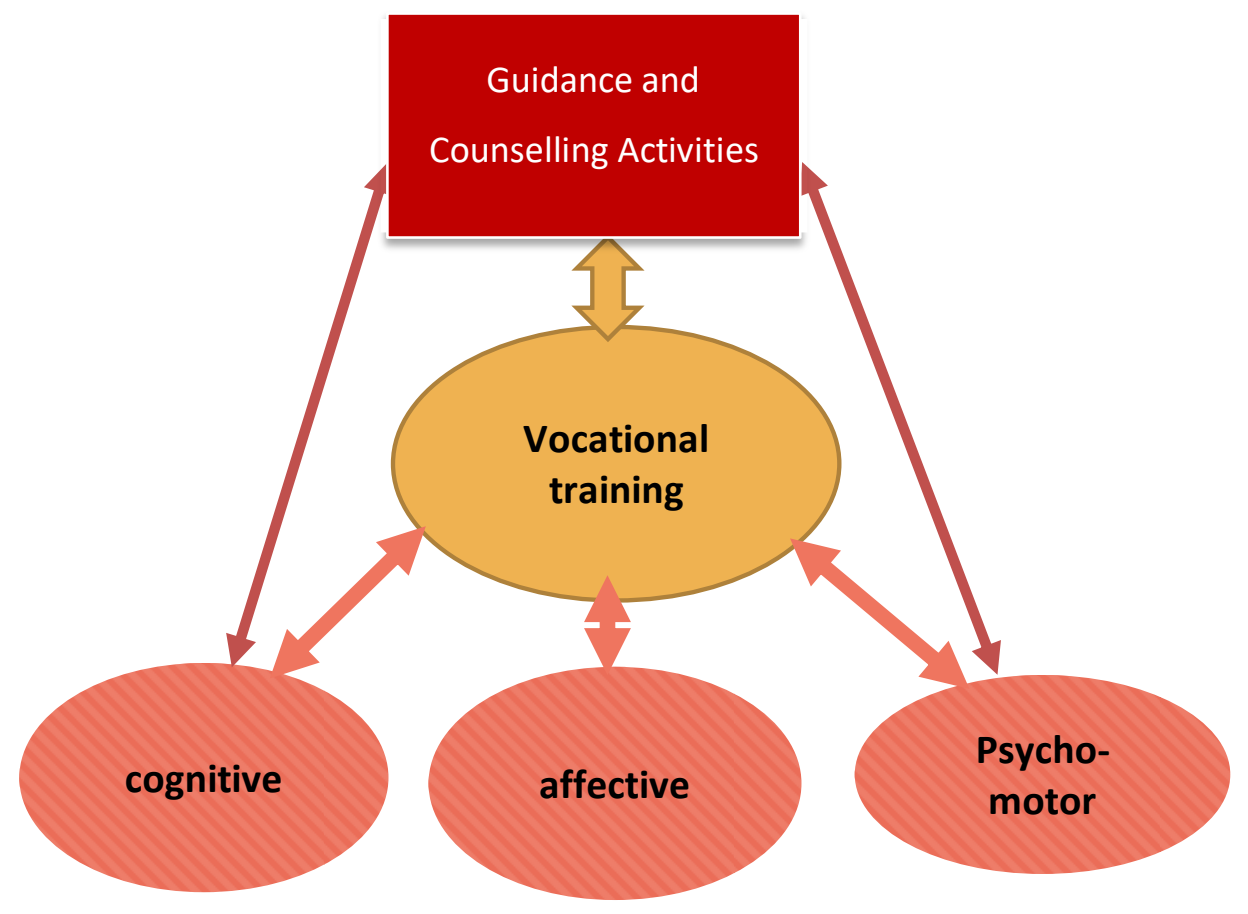


The interplay among the key human domains, namely, cognition, psycho-motor and affect eventually converge to define our primary life purpose - vocational development. The Social Cognitive Theory (Bandura, 1986) and the Social Cognitive Career theory (SCCT) (Lent, Brown \& Hackett, 1994) stress the importance of preliminary life activities in exploring our vocational interests and occupational choices, to establish our future career successes (Lent, 2005). Undeniably, the environment, the individual and the behaviour intricately interact to define our future goals. Our entire life activities, through childhood thus converge to influence our career plans, vocational orientations, and training. They also ultimately define our future roles and personalities. The proposed model simply emphasises our talents, skills, and educational endeavours to determine our future vocations. The following objectives are accordingly outlined to augment future guidance and counselling services within special schools in Ghana.

\section{Objectives to be achieved with the proposed counselling model}

1) train teachers in using the model

2) assess and identify pupils' individual disability areas upon admission

3) outline pupils' individual counselling needs

4) design suitable guidance activities for their needs

5) design guidance services for family members of pupils with special educational needs

\section{Target groups are:}

- pupils with special educational needs

- parents of family members of pupils with special educational needs

- the staff of pupils with special educational needs

\section{Conclusion}

The study on the whole, highlighted the immense importance of school guidance and counselling services for pupils with special educational needs. The benefits of the facility are numerous and critical to the pupils' fruitful education and development, although a lot more could be done to support the emotional and social development of pupils in special and inclusive schools. 


\section{Implications of the study findings to inclusive education in Ghana}

The study highlighted the significant role guidance and counselling services play in inclusive classrooms. It is reassuring to observe that objective two, strategy three of Ghana's proposed implementation plan on the national inclusive education draft policy, recommends training of focal persons in guidance and counselling. Such a facility will ensure professional and well-grounded guidance and counselling facilities within the various institutions. Secondly, the emphasis placed on teacher aides and the non-compliance of teachers regarding the use of corporal punishment in class requires urgent attention. The reduced use of corporal punishment will go a long way to reduce the number of hindrances and ultimately strengthen pupils' emotional and social development at school.

The use of guidance and counselling staff to intervene in the relationship issues of special needs pupils, both at school and home should be extended to all other inclusive schools. This aligns with the inclusive reform's emphasis on child-friendly schools. Pupils stand to benefit both emotionally and socially from such support services.

\section{Recommendations}

Following the importance of guidance and counselling services in the education of pupils with special educational needs, it is recommended that officers at various Regional Guidance and Counselling Units should liaise with the Ghana Education Service to post a trained guidance coordinator or counsellor in each inclusive or special school, for the implementation of professional services.

Officers from the Regional Guidance and Counselling Units should also liaise with the Special Education Unit officials to undertake bi-annual monitoring and evaluation visits to the various schools. Such activity will, for instance, ensure the redress of the various reported challenges related to inefficient service provision within the institutions.

Designing more gender sensitive guidance and counselling-related programmes in the various special and inclusive schools will enhance the growth and development of pupils with special educational needs. This will ensure that both male and female pupils benefit tremendously from the implemented services. 
Given that true educational and pedagogical change for social and educational inclusion must start early (McLaren, 2007), it is recommended that more emphasis be placed on professionalism at the various teacher training institutions in Ghana. This will redress the reported incidents of teachers' negative attitudes towards inclusive education and pupils with special educational needs. It is further recommended that the Special Education Unit organises bi-annual in-service training on inclusion for teachers in inclusive and special schools. Secondly, an inclusive-enriched curriculum should be factored into the teacher training institutional programmes for enhanced awareness among trainee teachers in Ghana.

\section{References}

Agbenyega, J. S. 2006. Corporal punishment in the schools of Ghana: Does inclusive education suffer. The Australian Educational Researcher 33(3), 107-122.

Agbenyega, J. 2007. 'Examining teachers' concerns and attitudes to inclusive education in Ghana'. International Journal of Wholeschooling 3(1), 41.

Allen, B. P. 2015. 'Every Person Is to Be Prized: Carl Rogers'. In Personality Theories $5^{\text {th }}$ Ed., 223-246. New York: Psychology Press.

Altun, C., Guven, G., Akgun, O. M., Akkurt, M. D., Basak, F., \& Akbulut, E. 2010. Oral health status of disabled individuals attending special schools. European journal of dentistry, 4(4), 361.

Babilonia, L. I. 2016. Integrating person-centered therapy with rational emotive behavioral therapy to treatment of alcohol use disorder in Hispanic armed forces members. Doctoral dissertation, Mississippi College.

Bitsika, V. \& Sharpley, C. F. 2004. Stress, anxiety and depression among parents of children with Autism Spectrum disorder. Journal of Psychologists and Counsellors in Schools 14(2), 151-161.

Charema, J., \& Eloff, I. 2011. Parents of children with hearing impairment accessing counselling services in Zimbabwe. Schedule of events for the twelfth Biennial Conference Windhoek, Namibia. Journal of International Association of Special Education, 12(1), 17-27.

Clark, M. A., \& Breman, J. C. 2009. School Counselor Inclusion: A Collaborative Model to Provide Academic and Social-Emotional Support in the Classroom Setting. Journal of Counseling \& Development, 87(1), 6-11. 
De Boer, A., Pijl, S. J., \& Minnaert, A. 2011. Regular primary schoolteachers' attitudes towards inclusive education: A review of the literature. International journal of inclusive education, 15(3), 331-353.

Department for Education and Skills (DfES). 2007. National Statistics. London: DfES. Gargiulo, R. M. 2010. Special education in contemporary society: An introduction to exceptionality. Thousand Oaks: Sage Publications.

Giangreco, M. F., Suter, J. C., \& Doyle, M. B. 2010. Paraprofessionals in inclusive schools: A review of recent research. Journal of educational and psychological consultation, 20(1), 41-57.

Gyimah, E. K., Sugden, D. \& Pearson, S. 2009. Inclusion of children with special educational needs in mainstream schools in Ghana: influence of teachers and children's characteristics. International Journal of Inclusive Education, 13(8), 787-804

Hamilton-Roberts, A. 2012. Teacher and counsellor perceptions of a school-based counselling service in South Wales. British Journal of Guidance \& Counselling, $40(5), 65-483$

Kuyini, A. B. \& Mangope, B. 2011. Student teachers' attitudes and concerns about inclusive education in Ghana and Botswana. International Journal of Whole Schooling 7(1), 21-37

Lent, R. W. 2005. A Social Cognitive View of Career Development and Counseling. In S. D. Brown \& R. W. Lent (Eds.), Career development and counseling: Putting theory and research to work (pp. 101-127). Hoboken, NJ, US: John Wiley \& Sons Inc.

Lent, R. W., Brown, S. D., \& Hackett, G. 1994. Toward a unifying social cognitive theory of career and academic interest, choice, and performance. Journal of vocational behavior, 45(1), 79-122.

Logan, A. 2006. The Role of the Special Needs Assistant Supporting Pupils with Special Educational Needs in Irish Mainstream Primary Schools. Support for Learning, 21(2), 92-99.

Lunenburg, F. C. (2012). Power and leadership: An influence process. International Journal of Management, Business, and Administration, 15(1), 1-9.

Nonis, K. P. \& Jernice, T.S.Y. 2011. Pre-service teachers' views about inclusion in Singapore, Schedule of events for the Twelfth Biennial Conference Windhoek, 
Namibia. Journal of the International Association of Special Education, 12(1), 39.

Obani, T.C. (Ed.) 2006. Special education and special educational needs in Obani.

Teaching pupils with special educational needs in the regular UBE Classrooms. Ibadan: Book Builders.

Ocloo, M. A. \& Subbey, M. 2008. Perception of basic education school teachers towards inclusive education in the Hohoe District of Ghana. International Journal of Inclusive Education 12(5 \& 6), 639-650.

Oluka, B. N., \& Eke, N. A. 2015. Managing children with learning disabilities in inclusive classroom: Roles of guidance/counsellors. Journal of Educational Policy and Entrepreneurial Research, 2(2), 53-59.

Pijl, S. J., Frostad, P., \& Flem, A. 2008. The social position of pupils with special needs in regular schools. Scandinavian Journal of Educational Research, 52(4), 387405.

Rose, C. A., Monda-Amaya, L. E., \& Espelage, D. L. 2011. Bullying perpetration and victimization in special education: A review of the literature. Remedial and Special Education, 32(2), 114-130.

Rose, R. \& O'Neil, A. 2009. Classroom support for inclusion in England and Ireland: an evaluation of contrasting models. Research in Comparative and International Education, 4(3), 250-261.

Simmons, B., \& Bayliss, P. 2007. The role of special schools for children with profound and multiple learning difficulties: is segregation always best? British Journal of Special Education, 34(1), 19-24.

Vanderpuye, I. 2013. Piloting inclusive education in Ghana: Parental perceptions, expectations and involvement. Unpublished doctoral thesis, Leeds: University of Leeds.

Warnock, M. 2005. Special educational needs: A new look. London: Philosophy of Education Society of Great Britain.

Warnock, M., \& Norwich, B. 2010. Special educational needs: A new look. Bloomsbury Publishing. 